\title{
Pemberdayaan Kelompok Tani Pattunggalengan di Kabupaten Takalar melalui inovasi budidaya bawang merah
}

\author{
Rahmawati ${ }^{1}$, \& Darmawan Risal ${ }^{\text {* }}$ \\ ${ }^{1}$ Fakultas Farmasi, Universitas Indonesia Timur, Indonesia \\ 2Fakultas Pertanian, Universitas Indonesia Timur, Indonesia \\ *darmawan.risal@uit.ac.id
}

\begin{abstract}
Shallots are one of the horticultural crops cultivated by the Pattunggalengan Farmer Groups in Banggae Village, Takalar Regency, whose production is decreasing. The decline in production is influenced by application inorganic systems and use of seeds that are not superior because they come from multiplied tillers and cultivation systems that are semi-manual. The purpose of this activity's to provide counseling and assistance on onion cultivation innovation in Pattunggalengan Farmer Groups, from selecting seeds, making planting demonstration plots, fertilizing, planting, watering and harvesting. The method used was discussion group forum and making of planting demonstration plot using Super Philip and drip irrigation. The soil $\mathrm{pH}$ condition demonstration plot location was 6.5 , which classified optimal but was given organic fertilizer to provide macro nutrients, shallot seeds by giving mankozeb fungicide with drip irrigation watering system on each sample bed. The yield obtained with $100 \mathrm{~kg}$ and the number of seeds were $250 \mathrm{~kg} / 100 \mathrm{~m} 2$. The counseling and mentoring that was carried out made the Pattunggalengan farmer know good soil cultivation, superior seeds and production resulting from the innovation of shallot cultivation.
\end{abstract}

\begin{abstract}
Abstrak Bawang merah adalah salah satu tanaman hortikultura yang dibudidayakan oleh Kelompok Tani Pattunggalengan di Desa Banggae Kabupaten Takalar yang produksinya semakin menurun. Penurunan produksi dipengaruhi oleh penerapan sistem pertanian anorganik dan penggunaan bibit yang tidak unggul karena berasal dari anakan yang di tanam secara berulang serta sistem budidaya yang masih bersifat semi manual. Tujuan kegiatan ini adalah memberikan penyuluhan dan pendampingan inovasi budidaya bawang merah kepada Kelompok Tani Pattunggalengan, dimulai dari pemilihan bibit, pembuatan demplot pertanaman, pemupukan, penanaman, penyiraman dan pemanenan. Metode yang digunakan adalah forum grup diskusi dan pembuatan demplot pertanaman menggunakan bibit super philip dan irigasi tetes. Kondisi $\mathrm{pH}$ tanah lokasi demplot pertanaman 6,5 yang tergolong optimal namun diberikan pupuk organik untuk menyediakan hara makro, penanaman bibit bawang merah dengan pemberian fungisida mankozeb dengan sistem penyiraman irigasi tetes pada setiap bedeng contoh. Hasil produksi yang diperoleh dengan bibit $100 \mathrm{~kg}$ adalah $250 \mathrm{~kg} / 100 \mathrm{~m} 2$. Penyuluhan dan pendampingan yang dilakukan membuat Kelompok Tani Pattunggalengan mengetahui pengolahan tanah yang baik, bibit unggul serta produksi yang dihasilkan dari inovasi budidaya bawang merah.
\end{abstract}

Keywords: empowerment; shallot; production; drip irrigation

\section{ఠ OPEN ACCESS}

Citation: Rahmawati, \& D. Risal. (2021). Pemberdayaan Kelompok Tani Pattunggalengan di Kabupaten Takalar melalui inovasi budidaya bawang merah. Riau Journal of Empowerment, 4(1), 49-57. https://doi.org/10.31258/raje.4.1.49$\underline{57}$

Received: 2020-12-02 Revised: 2021-04-19 Accepted: 2021-04-21

Language: Bahasa Indonesia (id)

Funding: Dana hibah bantuan Program Kemitraan Masyarakat (PKM) Kemenristek/Brin Republik Indonesia

ISSN 2623-1549 (online), 2654-4520 (print)

(c) 2021 Rahmawati, \& Darmawan Risal. Author(s) retain the copyright of article published in this journal, with first publication rights granted to Riau Journal of Empowerment. The article is licenced under Creative Commons Attribution 4.0 International License. This license permits unrestricted use, distribution, and reproduction in any medium, provided the original author and source are credited. 


\section{PENDAHULUAN}

Kecamatan Mangarabombang adalah satu satunya wilayah yang memproduksi bawang merah (Alium ascalonicum L.) di wilayah Kabupaten Takalar Provinsi Sulawesi Selatan. Produksi bawang merah yang dihasilkan dari tahun 2015 - 2019 di Kecamatan Mangarabombang mengalami fluktuatif yaitu periode 2015 - 2016 menurun sekitar 45,12\% dari produksi 90 ton/ha sedangkan pada tahun 2017 - 2019 mengalami peningkatan dengan produksi mencapai 14 ton/ha (BPS Kabupaten Takalar, 2019). Peningkatan produksi rata-rata bawang merah di Kecamatan Mangarabombang secara keseluruhan ini tidak mempengaruhi hasil bawang merah di kelompok tani pattunggalengan Desa Banggae yang hanya memperoleh produksi rata-rata 1,5-2 ton/ha hingga pada tahun 2019. Angka ini merupakan hasil yang terendah dibandingkan dengan produksi sayuran lainnya di kelompok tani Pattunggalengan

Minimnya pengetahuan petani tentang penggunaan jenis bibit unggul, pemeliharaan dan penerapan inovasi budidaya membuat mereka hanya menggunakan pengalaman yang seadanya sebagai dasar untuk membudidayakan bawang merah. Petani bawang merah di kelompok Pattunggalengan pernah mendapatkan bibit bawang merah dari Dinas Pertanian Kabupaten Takalar namun pendampingan selama penanaman tidak mereka peroleh dan tidak pernah mengikuti pelatihan/penyuluhan tentang cara budidaya bawang merah yang benar. Pendampingan dan penyuluhan terhadap tujuh standar budidaya bawang merah sangat perlu dilaksanakan khususnya dalam pemilihan bibit tanaman, pemupukan dan pengendalian organisme pengganggu tanaman (Sholeh et al., 2017). Pada beberapa kegiatan pendampingan dan penyuluhan budidaya bawang merah sebelum pertanaman sangat berdampak pada partisipasi dan pengetahuan petani. Kegiatan penyuluhan dan pendampingan pada kegiatan pemilihan benih dapat meningkatkan pengetahuan petani sekitar $73 \%$, penanaman $100 \%$ dan pada saat kegiatan pemeliharaan $27 \%$. Selain itu, sistem pendampingan dan penyuluhan dapat berdampak pada tingkat pengetahuan dan kepuasan petani dengan usaha budidaya yang mereka laksanakan yang mencapai 90 - 100\% (Marlin et al., 2020).

Pengolahan tanah sebagai media tanam bawang merah di kelompok tani Pattunggalengan yang dilakukan secara semi manual sudah berlangsung cukup lama. Sama halnya dengan penggunaan pupuk pada tanaman bawah merah yang masih melakukan pemupukan semiorganik. Pengolahan dan penggunaan pupuk berdampak pada sifat fisik dan kimia tanah. Wilayah pertanaman di kelompok tani Pattunggalengan yang berada pada sekitaran pesisir pantai menjadikan reaksi tanahnya berada pada kondisi agak masam serta penggunaan pupuk kimia pada bawang merah menjadikan tanaman mudah terserang penyakit. Untuk menjaga kestabilan hara dan penekanan Organisme Pengganggu Tanaman (OPT) dapat dilakukan dengan menggunakan pupuk semiorganik. Interaksi perlakuan dengan pemupukan semiorganik dapat menjadikan perubahan pada sifat kimia tanah pada semua perlakuan dengan peningkatan $\mathrm{pH}$ sebesar 3,42\% dari 6,44 menjadi 6,66. Namun, penggunaan pupuk organik yang sudah ditingkatkan hara makronya (Nitrogen, Fosfor, Kalium) melalui proses pembakaran dan pengolahan menjadi pupuk organik tanaman pada tanah miskin hara dapat meningkatkan produksi tanaman (Risal, 2020).

Produksi bawang merah yang rendah menjadikan petani di kelompok tani Patunggalengan tidak mampu membuat inovasi budidaya dalam bentuk teknologi pengolahan dan penyiraman. Sistem penyiraman manual menjadikan tanah dan bawang merah biasanya mengalami kekeringan dan tidak bisa tumbuh secara optimal. Sistem pengairan di kelompok tani Pattunggalengan dilakukan dengan hanya membuat sumur-sumur buatan di sekitar lahan, padahal pada musim kemarau persediaan air sangat kurang sehingga tanaman bawang merah 
yang seharusnya dilakukan penyiraman dua kali sehari hanya dilakukan satu kali dalam sehari. Proses penyiraman oleh petani dilakukan dengan sistem manual dengan menggunakan ember dan baskom yang di rakit secara sederhana. Perlakuan ini yang membuat petani harus menambah waktu dan tenaga untuk dapat membuat tanaman bawang merah tetap memperoleh air untuk pertumbuhannya.

Rahmawati, \& Risal

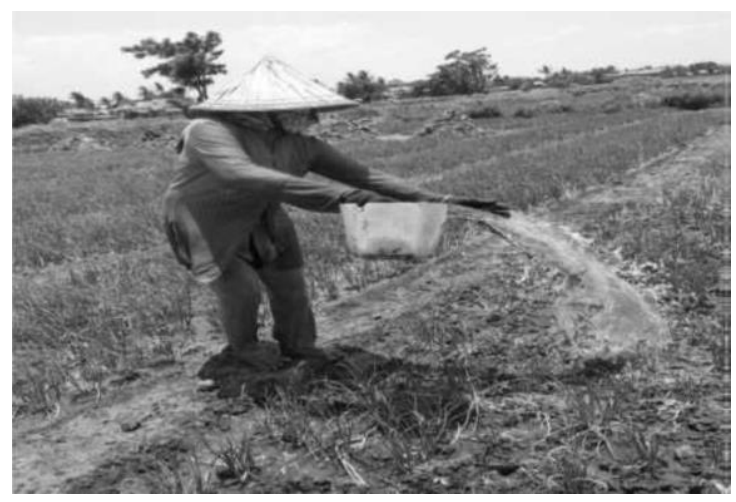

Gambar 1. Penyiraman secara manual oleh petani di Kelompok Tani Pattunggalengan

Salah satu cara penggunaan air secara hemat untuk pemenuhan kebutuhan tanaman yaitu dengan menggunakan teknologi irigasi hemat air berupa irigasi tetes atau irigasi sprinkler. Penelitian (Irmak et al., 2011) mengemukakan bahwa efisiensi pemakaian air irigasi tetes dapat mencapai $95 \%$, sedangkan irigasi sprinkler hanya dapat mencapai $85 \%$. Selanjutnya, efisiensi pemakaian air irigasi tetes dengan menggunakan 2, 4, dan 5 buah emiter per tanaman berturut-turut 82,88 , dan $92 \%$ (Idrus \& Surya, 2019). Permeabilitas yang didapatkan 9,823 $\mathrm{cm} / \mathrm{jam}(192,914 \mathrm{ml} / \mathrm{jam}$ atau $0,0535 \mathrm{ml} / \mathrm{s})$, debit yang rata-rata $0,65079 \mathrm{ml} / \mathrm{s}$ dengan keseragaman emisi sekitar 97 \% (Arianto \& Lili, 2019).

Tujuan dari kegiatan pengabdian masyarakat ini adalah memberikan penyuluhan dan pendampingan kepada kelompok tani Pattunggalengan tentang teknik budidaya bawang merah yang tepat, di mulai dari pemilihan bibit, pembuatan demplot pertanaman, pemupukan, penanaman, penyiraman dan pemanenan. Kelompok tani Pattunggalengan memiliki potensi untuk meningkatkan produksi bawang merah sehingga berdampak baik pada pendapatan ekonominya. Berdasarkan observasi dan diskusi dengan petani terdapat beberapa permasalahan yang dihadapi saat ini yaitu; minimnya pengetahuan tentang pembudidayaan bawang merah, pengolahan lahan dan irigasi penyiraman masih menggunakan teknik semi manual serta hasil panen dengan kualitas rendah yang berdampak pada harga rendah.

\section{METODE PENERAPAN}

Kegiatan pengabdian kepada masyarakat ini bertempat di Dusun Bolo Desa Banggae Kecamatan Mangngarabombang Kabupaten Takalar yang di mulai Agustus hingga November 2019. Metode yang digunakan dalam pengabdian masyarakat ini adalah forum grup diskusi (FGD) dan pembuatan demplot pertanaman. Forum group diskusi dilakukan dengan memberian ceramah dan panduan serta penjelasan inovasi budidaya bawang merah yang dimulai dari persiapan lahan, pengolahan dan pemeliharaan. Pembuatan demplot pertanaman merupakan model partisipasi aktif yang dilakukan dengan melibatkan petani langsung di lapangan dengan melakukan tahapan budidaya termasuk pemasangan irigasi tetes untuk penyiraman bawang merah. Metode partisipasi aktif akan langsung memberikan pengetahuan dan pemahaman kepada petani mengenai inovasi budidaya bawang merah yang baik yang 
dimulai dari pengolahan lahan, persiapan benih, penyiraman, pemeliharaan hingga pemanenan. Penilaian ketercapaian kegiatan pengabdian ini dilihat dari kemampuan petani menerapkan hasil penyuluhan di lapangan melalui keterampilan dalam pengolahan dan budidaya bawang merah serta produksi yang diperoleh dari penerapan inovasi.

\section{Tahapan penyuluhan}

Persiapan dilakukan dengan menyiapkan bahan dan peralatan yang akan digunakan dalam penyuluhan berupa materi dan dokumentasi budidaya bawang merah yang baik. Penyuluhan dilakukan dengan menyampaikan konsep budidaya yang diawali dari pemilihan bibit, pengolahan tanah, penyiraman, pemeliharaan hingga pemanenan. Penyuluhan ini menggunakan laptop dan LCD untuk menayangkan materi power point yang dilengkapi dengan gambar-gambar.

Dalam melakukan penyuluhan, diselingi dengan tanya jawab secara langsung tentang tanggapan dan pemecahan masalah yang dihadapi oleh petani. Pemanfaatan media elektronik sangat membantu petani dalam memahami materi yang diberikan. Selain itu, materi diberikan kepada petani sebagai bahan referensi dalam melakukan budidaya pertanaman bawang merah.

\section{Pembuatan demplot pertanaman bawang merah}

Lahan yang akan dijadikan sebagai demplot pertanaman adalah milik anggota kelompok tani Pattunggalengan yang ada di Desa Banggae Kecamatan Manggarabombang. Demplot yang dibuat berukuran $1 \mathrm{~m}$ x $20 \mathrm{~m}$ dengan jarak tanam yang digunakan adalah $15 \mathrm{~cm}$ x $20 \mathrm{~cm}$ sehingga populasi tanaman dalam satu demplot adalah 666 biji. Pendampingan yang dilakukan pada pembuatan demplot pertanaman dimulai dari pengolahan lahan dengan menggunakan traktor tangan secara merata pada areal demplot pertanaman. Tanah yang sudah terolah rata dibentuk bedengan setinggi $30 \mathrm{~cm}$ yang mengelilingi pinggiran bedengan. Sebelum pemberian pupuk dasar, dilakukan pengambilan sampel tanah terganggu secara acak dan komposit yang mewakili lahan pertanaman untuk dilakukan analisis $\mathrm{pH}$ di laboratorium. Tujuannya adalah untuk mengetahui tingkat salinitas tanah dan pemberian dosis pupuk organik pada bawang merah.

\section{Pembuatan irigasi tetes dan penanaman pada demplot pertanaman bawang merah}

Pembuatan irigasi tetes menggunakan sumber air yang berasal dari sumur buatan yang di areal pertanaman. Langkah awal dimulai dengan pemasangan instalasi mesin air yang diteruskan pada tandon air berkapasitas 1300 L. Pada bagian tandon yang terpasang kerang dilakukan pemasangan instalasi irigasi tetes menuju demplot tanam sesuai dengan jarak tanam yang telah ditentukan. Setelah terpasang, dilakukan pemasangan plastik mulsa pada demplot dengan mengukur luasan dan demplot tanaman. Pelubangan plastik mulsa sebagai titik lubang dilakukan sesuai dengan jarak tanam yang telah diukur dan selanjutnya dilakukan penanaman bibit bawang merah.

\section{HASIL DAN KETERCAPAIAN SASARAN}

Pengabdian kepada masyarakat di kelompok tani Pattunggalengan telah dilaksanakan pada bulan November 2019. Pengabdian ini memakan waktu selama satu musim pertanaman bawang merah karena menunggu hasil produksi pertanaman pada demplot pertanaman. 
Pemberian penyuluhan dan pertanaman dengan menggunakan bibit unggul super philip, pupuk organik, inovasi penggunaan irigasi tetes untuk penyiraman sebagai salah satu budidaya yang berdampak pada perbaikan kesuburan dan peningkatan produksi bawang merah.

Rahmawati, \& Risal

\section{Kegiatan penyuluhan budidaya bawang merah (super philip)}

Pengabdian ini merupakan satu rangkaian yang saling mendukung dan sangat berpengaruh terhadap keberhasilan budidaya. Tim pengabdian ini melibatkan mahasiswa dari Fakultas Pertanian dan Fakultas Farmasi Universitas Indonesia Timur Makassar yang keseluruhannya berjumlah 2 orang. Teknis Forum Group Diskusi (FGD) dilakukan sebanyak dua kali. FGD pertama yang terdiri dari tim internal dan mahasiswa. Pada tahap ini melakukan persiapan perizinan dari pihak Universitas ke BKPMD untuk melakukan kegiatan pengabdiaan kepada masyarakat, serta tim internal universitas dan mahasiswa mendiskusikan solusi yang akan diberikan kepada kelompok tani Dusun Bolong Desa Banggae Kecamatan Mangarabombang Kabupaten Takalar tentang budidaya bawang merah. Diskusi banyak dilakukan kepada kelompok tani tentang budidaya bawang merah super philip mulai dari pemilihan bibit, pengolahan tanah, pembuatan demplot, pemberian pupuk organik sebelum pertanaman serta penanaman (Gambar 2). Pada kegiatan ini dilakukan ceramah dan tanya jawab secara langsung kepada petani terkait masalah dan kendala yang dihadapi selama ini dalam melakukan usaha tani bawang merah.

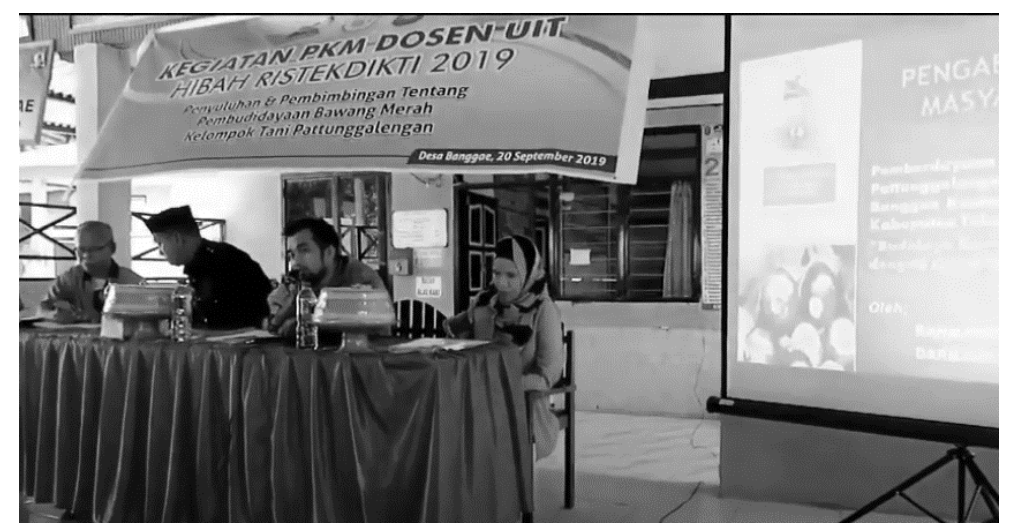

Gambar 2. FGD bersama kelompok tani Pattunggalengan tentang budidaya bawang merah

Pada kegiatan ini, diperoleh informasi bahwa hal yang paling mendasar dan menjadi masalah petani adalah tidak adanya informasi mengenai potensi penggunaan bibit unggul super philip yang dapat tumbuh pada beberapa kondisi tanah dan wilayah. Jenis ini mampu memberikan produksi yang tinggi dibandingkan dengan menggunakan bibit lokal yang ditanam secara berulang oleh petani di kelompok tani Pattunggalengan. Pada pengujian bibit tanaman pada enam varietas bawang merah, keseluruhan varietas bawang merah yang salah satunya adalah super philip memberikan hasil beda nyata dengan kontrol, sedangkan pada aplikasi dengan tingkat salinitas konsentrasi berbeda juga berbeda nyata dengan kontrol. Pada perlakuan kontrol, keseluruh enam varietas bawang merah perlakuan salinitas varietas bauji, bima brebes, super philip, tajuk, katumi dan trisula menunjukan berbeda nyata dan memiliki nilai tertinggi di bandingkan perlakuan konsentrasi yang lain sedangkan antara perlakuan konsentrasi 8.000 dan 12.000 ppm interaksi nyata terlihat pada varietas super philip, katumi dan trisula, untuk varietas bauji, bima brebes dan tajuk tidak berbeda nyata (Hadianti dan Damanhuri, 2019). 


\section{Pendampingan Pengambilan Sampel Tanah dan Analisis pH di Laboratorium}

Pada kegiatan ini dilakukan pendampingan kepada mahasiswa yang terlibat untuk melakukan pengambilan sampel tanah (Gambar 3). Tujuannya adalah untuk mengetahui kadar $\mathrm{pH}$ tanah yang ada di lokasi milik petani kelompok tani Pattunggalengan. Tingkat kemasaman tanah sangat berpengaruh pada ketersediaan hara pada tanah. Mahasiswa selanjutnya melakukan analisis pH di laboratorium (Gambar 3) yang hasil analisisnya adalah 6,5. Hasil analisis ini memberikan penjelasan bahwa tingkat kemasaman tanah pada areal pertanaman petani adalah agak masam. Kondisi agak masam cukup baik dijadikan sebagai media tanam. pH tanah pada lahan milik petani agak masam karena masih terdapat bahan organik yang berasal dari pertanaman padi yang dilakukan pada musim rendeng dan gadu 1 sebelumnya. Adanya sisasisa jerami pada batang dan akar yang tertinggal dan melapuk meningkatkan kandungan bahan organik tanah dan berdampak pada perbaikan pH tanah (Supadma et al., 2020). Rasio C/N yang dimiliki jerami sebesar 10,28\% dan sangat berpengaruh terhadap dekomposisi bahan organik dan meningkatkan $\mathrm{pH}$ tanah karena bahan organik yang bersifat humus dapat mengikat hidrogen (Pane et al., 2014).

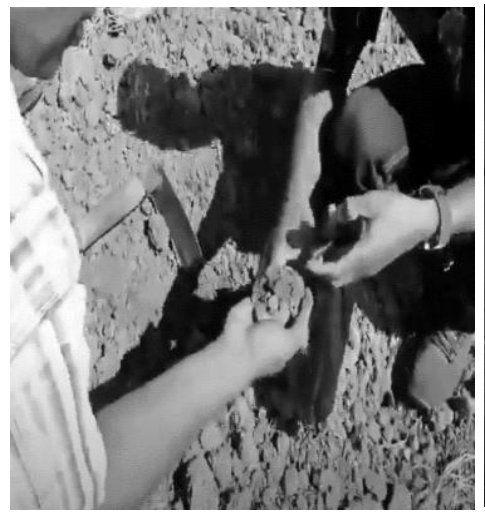

(a)

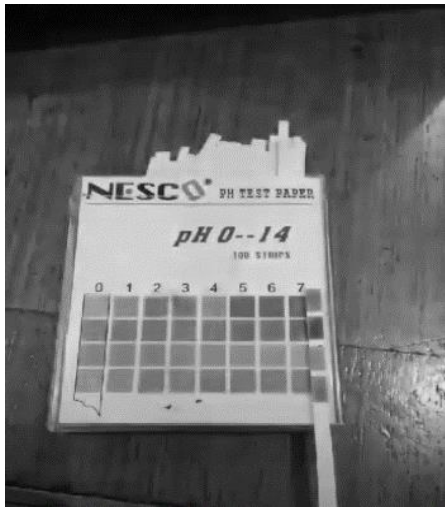

(b)

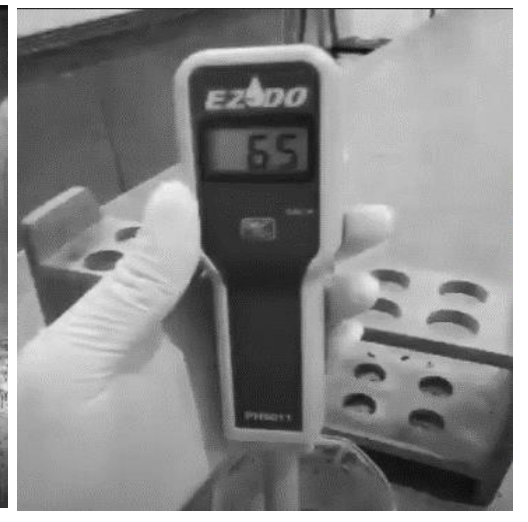

(c)

Gambar 3. (a) Pengambilan sampel tanah top soil secara komposit dan memasukkannya pada media, (b) pengukuran $\mathrm{pH}$ menggunakan kertas lakmus (c) pengukuran $\mathrm{pH}$ tanah metode $\mathrm{H} 2 \mathrm{O}$ di laboratorium

\section{Pendampingan Pengolahan Tanah, Pembuatan Irigasi Tetes dan Penanaman Bawang Merah}

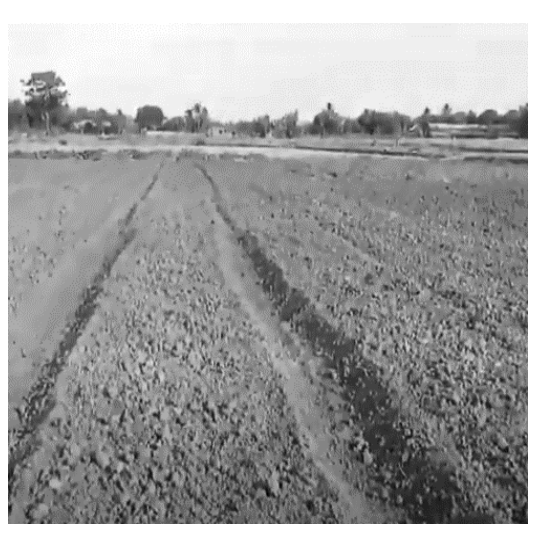

(a)

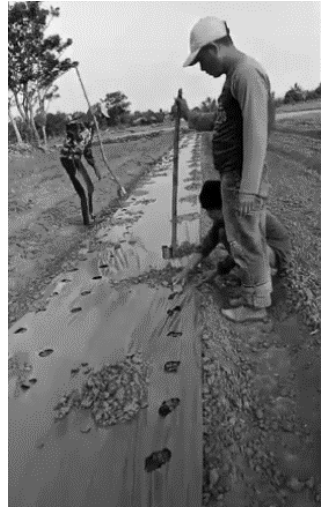

(b)

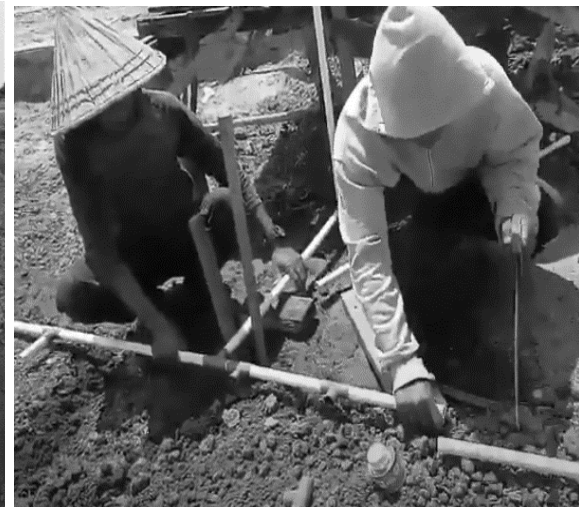

(c)

Gambar 4. (a) Pembuatan demplot, (b) pemasangan mulsa plastic, dan (c) pemasangan instalasi irigasi tetes 
Kegiatan ini merupakan hasil dari proses FGD dan penyuluhan kepada kelompok tani Rahmawati, \& Risal Pattunggalengan yang dengan pendampingan di lapangan dapat melakukan proses pengolahan tanah, pembuatan demplot pertanaman, pemasangan plastik mulsa, pembuatan irigasi tetes dan penanaman. Kegiatan ini dilakukan secara bertahap oleh petani yang dimulai dari pengolahan tanah. Pengolahan dilakukan dengan menggunakan traktor tangan. Efisiensi waktu dan tenaga dalam budidaya sangat perlu dilaksanakan untuk memudahkan petani mengatur waktu tanam. Penggunaan mulsa plastik dilakukan untuk menekan pertumbuhan mulsa dan dapat mengontrol kapasitas layu yang dipengaruhi oleh tingginya sinar matahari maupun rendahnya curah hujan yang terjadi.

Pendampingan yang sangat penting dan merupakan hal baru pada petani adalah pembuatan instalasi irigasi tetes. Pada kegiatan ini, dimulai dengan memasang mesin air pada sumur sederhana yang telah ada di lahan milik petani. Selanjutnya adalah mengalirkan air menuju tandon penampung kapasitas $1.300 \mathrm{~L}$. Air akan mengalir pada beberapa cabang kerang pipa (emiter) yang pada ujungnya terdapat selang karet menuju setiap titik tanam bawang merah. Pada selang karet tersebut diberikan lubang kecil sebagai tempat tetes atau keluarnya air untuk tanaman. Petani hanya melakukan buka tutup kerang kontrol yang terdapat pada pipa (Gambar 5) jika akan melakukan pnyiraman pada tanaman bawang merah. Penggunaan irigasi tetes pada tanaman bawang sangat bermanfaat pada tanaman bawang merah karena selain efisiensi penggunaan air, juga dapat menjaga keberlangsungan kebutuhan air oleh tanaman. Penggunaan teknologi irigasi tetes dapat menghemat penggunaan air mencapai 95\%, sedangkan irigasi sprinkler hanya dapat mencapai 85\% (Irmak et al., 2011) sedangkan efisiensi pemakaian air irigasi tetes dengan menggunakan 2, 4, dan 5 buah emiter per tanaman berturutturut 82, 88, dan 92\% (Idrus \& Surya, 2019).

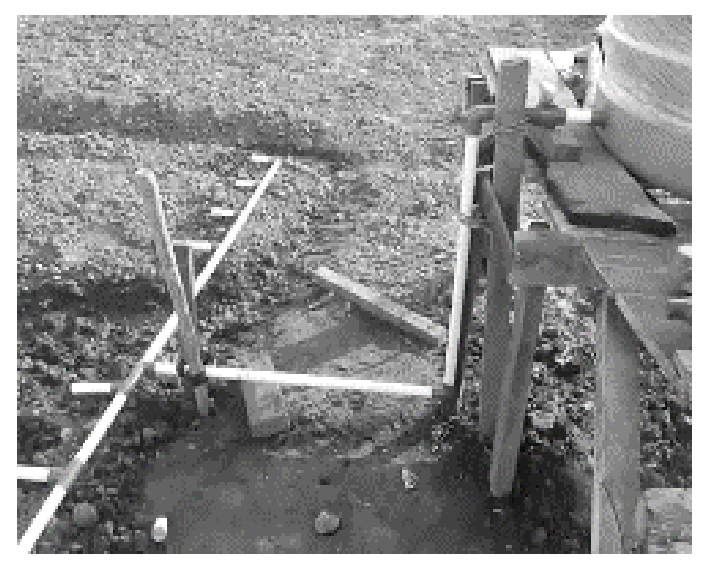

(a)

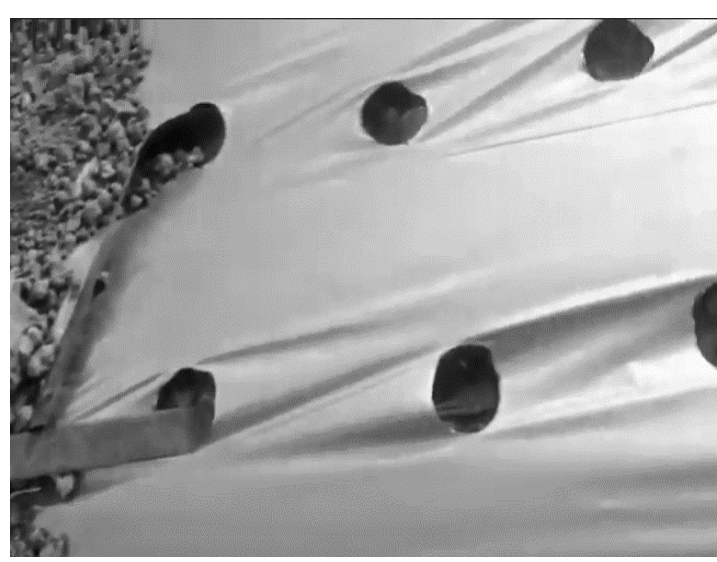

(b)

Gambar 5. (a) Instalasi irigasi tetes yang dialirkan dari keran tendon air, (b) jaringan selang irigasi tetes yang melalui titik lubang tanam

Pemanenan bawang merah pada demplot dilakukan setelah berumur 65 hari setelah tanam. Hasil produksi berat segar bawang merah yang diperoleh sebanyak $25 \mathrm{~kg}$ dengan luas panen $100 \mathrm{~m}^{2}$. Jika dibandingkan dengan pertanaman dengan menggunakan media tanam aram sekam, kompos dan tanah dan model penyiraman tradisional, hasil yang diperoleh adalah 141 - 158 umbi per $\mathrm{m}^{2}$. Hasil tersebut dihasilkan dari 4 - 5 gram/umbi, sehingga dalam setiap luasan hanya menghasilkan $1,58 \mathrm{~kg} / \mathrm{m}^{2}$ (Rosliani et al., 2016). 
Penerapan inovasi budidaya bawang merah pada kelompok tani Pattunggalengan memberikan hasil yang optimal dibandingkan dengan metode semi manual yang dilakukan sebelumnya. Penggunaan bibit unggul dan pemberian pupuk organik serta penyiraman dengan menggunakan irigasi tetes memberikan pengaruh lebih baik dibandingkan dengan pemberian air cara petani yang hanya menggunakan gembor. Dampak yang diperoleh dari kegiatan pengabdian ini adalah adanya partisipasi aktif dari petani untuk langsung mengaplikasikan inovasi budidaya pada demplot pertanaman yang disampaikan pada saat penyampaian materi FGD. Kegiatan ini dinilai sangat bermanfaat dan berhasil, terbukti dari partisipasi dan pengetahuan petani melakukan inovasi budidaya secara berkelompok sehingga produksi yang diperoleh juga meningkat. Terkait kendala, peluang dan faktor lain yang menjadi masalah dalam penerapan inovasi budidaya bawang merah di kelompok tani Pattunggalengan dilakukan melalui komunikasi aktif untuk mendukung keberlanjutan produktivitas bawang merah di wilayah ini. Berikut hasil bawang merah pada lokasi demplot pertanaman yang dihitung bersama dengan mahasiswa dan anggota Kelompok Tani (Gambar 6)

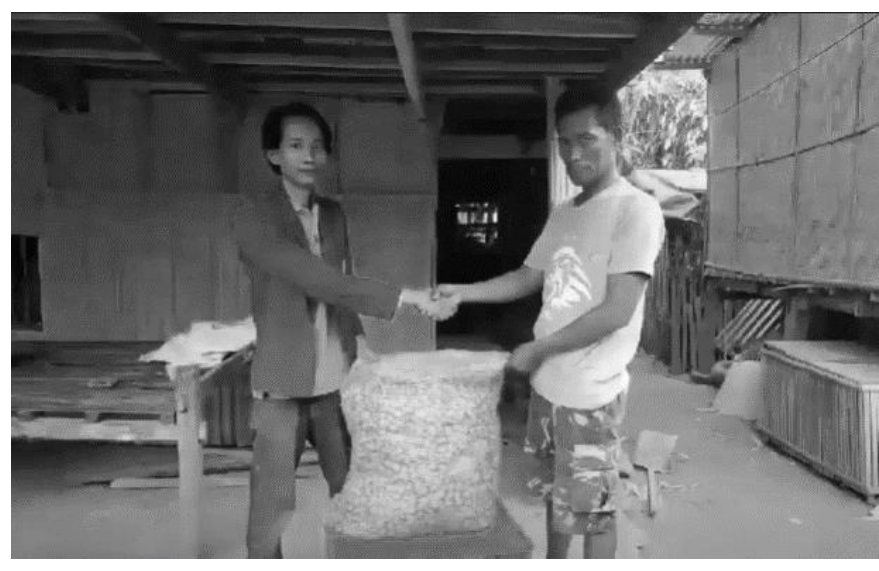

Gambar 5. Produksi bawang merah super philip yang ditanam pada demplot pertanaman

\section{KESIMPULAN}

Kegiatan pengabdian kepada masyarakat memberikan dampak yang sangat bermanfaat kepada kelompok tani Pattunggalengan. Dengan adanya penyuluhan, petani dapat mengetahui inovasi budidaya bawang merah dan pemanfaatan super philip, pengolahan lahan dan pembuatan media tanaman yang baik. Pendampingan kepada petani menggunakan irigasi tetes memberikan pengetahuan dan hasil yang baik karena berdampak pada efisensi penggunaan air, perbaikan pertumbuhan dan produksi, penghematan waktu kerja sehingga mereka dapat melakukan aktivitas lain dalam waktu yang sama pada lahan pertaniannya tanpa harus terfokus pada kebutuhan air tanaman.

\section{UCAPAN TERIMA KASIH}

Kegiatan pengabdian kepada masyarakat ini dilakukan dengan sumber dana hibah bantuan Program Kemitraan Masyarakat (PKM) dari Ristek Dikti dengan nomor kontrak 1596/UIT.2.00/F0.PJ/VI/2019 tanggal 21 Juni tahun 2019. Objek yang menjadi lokasi penelitian adalah Kelompok Tani Pattunggalengan Desa Banggae Kecamatan Mangarabombang Kabupaten Takalar. Kami dari tim pengabdian mengucapkan terimakasih kepada Ristek Dikti atas bantuan dana hibah yang diberikan, serta kepada masyarakat, ketua 
dan seluruh anggota kelompok tani Pattunggalengan yang telah memberikan waktu dan kerjasamanya sehingga kegiatan pengabdian ini dapat terlaksana dengan baik. Semoga apa yang dihasilkan dari kegiatan ini dapat memberikan kontribusi yang berkelanjutan untuk dapat

Rahmawati, \& Risal peningkatan produksi hortikutura nasional.

\section{Daftar Pustaka}

1. Arianto, Lili. (2019). "Rancangan Irigasi Tetes untuk Tanaman Bawang Merah (Allium ascalonicum L.) Sistem Vertical Agriculture (Verticulture)." http://repository.usu.ac.id

2. BPS Kabupaten Takalar. (2019, November 21). Statisik Pertanian Hortikultura Kabupaten Takalar. https://takalarkab.bps.go.id/publication/download.html?nrbvfeve

3. Hadianti, F. N., \& Damanhuri, D. (2019). Toleransi Enam Varietas Tanaman Bawang Merah (Allium ascalonicum L.) pada Cekaman Salinitas. Jurnal Produksi Tanaman, 7(12). http://doi.org/10.21176/protan.v6i4.674

4. Idrus, M. I., \& Surya, S. (2019). Penerapan Irigasi Tetes Emiter Tali Dengan Bebagai Selang Waktu Irigasi Pada Tanaman Semangka. Jurnal Penelitian Pertanian Terapan, 19(2), 127-131. https://doi.org/10.25181/jppt.v19i2.1447

5. Irmak, S., Odhiambo, L. O., Kranz, W. L., \& Eisenhauer, D. E. (2011). Irrigation efficiency and uniformity, and crop water use efficiency. https://digitalcommons.unl.edu

6. Marlin, M., Sitorus, A., Solihin, M., Romeida, A., \& Herawati, R. (2020). Pemberdayaan Masyarakat Pesantren Ar-Rahmah, Rejang Lebong dalam Memanfaatkan Lahan Pekarangan dengan Budi Daya Bawang Merah. Agrokreatif: Jurnal Ilmiah Pengabdian kepada Masyarakat, 6(1), 53-61. https://doi.org/10.29244/agrokreatif.6.1.53-61

7. Risal, D. (2020). "Uji Pupuk Organik untuk Pertumbuhan Cabai Keriting pada Tanah Miskin Hara." Jurnal Ecosolum 9.1: 19-27. http://dx.doi.org/10.20956/ecosolum.v9i1.8667

8. Pane, M. A., Damanik, M. M. B., \& Sitorus, B. (2014). Pemberian bahan organik kompos jerami padi dan abu sekam padi dalam memperbaiki sifat kimian tanah ultisol serta pertumbuhan tanaman jagung. Jurnal Agroekoteknologi Universitas Sumatera Utara, 2(4), 101546. https://jurnal.usu.ac.id/index.php/agroekoteknologi

9. Rosliani, R., Hilman, Y., Hidayat, I. M., \& Sulastrini, I. (2016). Teknik Produksi Umbi Mini Bawang Merah Asal Biji (True Shallot Seed) dengan Jenis Media Tanam dan Dosis NPK yang Tepat di Dataran Rendah. http://repository.pertanian.go.id/handle/123456789/947

10. Sholeh, M. S., Sari, S. K., \& Hasin, H. (2017, October). Penyuluhan Standar Operasional Prosedur (SOP) Budidaya Bawang Merah Bagi Petani di Desa Ponjanan Barat Kecamatan Batumarmar. In Seminar Nasional Hasil Pengabdian Kepada Masyarakat (Vol. 1, No. 1, pp. 215-218). http://senias.uim.ac.id/index.php/senias_2017/article/view/58

11. Supadma, AA Nyoman, I. Made Dana, and I. Dewa Made Arthagama. (2020). "Peningkatan Hasil Bawang Merah dan Perubahan Sifat Kimia Tanah dengan Pemupukan Berimbang Semi Organik pada Tanah Inceptisol." Agrotrop: Journal on Agriculture Science 10.1: 67-76. https://doi.org/10.24843/AJoAS.2020.v10.i01.p08 